A Laboratory Miniproject in Plant Disease Diagnosis

Author(s): A. B. A. M. Baudoin

Source: The American Biology Teacher, Vol. 48, No. 7 (Oct., 1986), pp. 413-415+418-419

Published by: University of California Press on behalf of the National Association of Biology

Teachers

Stable URL: http://www.jstor.org/stable/4448355

Accessed: 18/02/2014 09:55

Your use of the JSTOR archive indicates your acceptance of the Terms \& Conditions of Use, available at http://www.jstor.org/page/info/about/policies/terms.jsp

JSTOR is a not-for-profit service that helps scholars, researchers, and students discover, use, and build upon a wide range of content in a trusted digital archive. We use information technology and tools to increase productivity and facilitate new forms of scholarship. For more information about JSTOR, please contact support@ jstor.org. 
How-To-Do-It

\section{A Laboratory Miniproject in Plant Disease Diagnosis}

\author{
A.B.A.M. Baudoin
}

An exercise in disease diagnosis by proving the pathogenicity of a microorganism following Koch's Postulates is an important part of most plant pathology and some microbiology laboratory courses. Such an exercise fits in general biology teaching as well; it would be a useful part of courses in botany, microbiology and mycology because: (1) the principles for proving pathogenicity are common to pathogens of animals, humans and plants; (2) it provides practice in the methods used to study fungal and bacterial pathogens; and (3) it provides an introduction to microorganisms that cause economically important plant diseases.

In most such exercises, all students in a class are provided with identical diseased specimens (e.g. Fulton 1981). This is most convenient to the instructor, but at the same time it eliminates some of the challenge and satisfaction for the students. Since all procedures are exactly prescribed, it results in less appreciation and understanding of the methods and the pitfalls encountered in diagnosing a disease. Providing each student with a different "unknown" disease is more true to life but has been difficult because of the logistics involved in providing a variety of diseases and of providing different healthy host plants at the right stage for inoculation.

The aim of this article is to describe procedures and resource materials for a laboratory "miniproject" in plant disease diagnosis, where each student studies a different "unknown" plant disease by isolating the suspected pathogen and determining whether the organism isolated actually caused the disease. Storage diseases of fruits and vegetables provide suitable pathogens for study, because there is a wide variety of host-parasite systems available, they are easily handled without need for greenhouse facilities, and healthy hosts at the right stage for inoculation can be obtained from supermarkets at any time of the year. Isolation from fleshy plant parts is usually easy compared to isolation from leaves or roots.

\section{Discovery of the Causes of Disease}

Through most of human history, the causes of diseases of humans, animals and plants remained obscure. Occurrence of disease was variously attributed to a human's sin, the wrath of the gods, nutritional disorganization of the body's juices or to an unfavorable environment (temperature, soil, wind, etc.) (Whetzel 1918). It was commonly observed that any animal or plant body soon after death would crawl with worms and maggots, and it was a plausible conclusion that these arose spontaneously from the dead tissues. After the $1600 \mathrm{~s}$, however, most scientists discounted this version of the theory of spontaneous generation.

Following the development of microscopes, scientists found bacteria and other microorganisms in large numbers in diseased plant or animal tissue, and the idea that these were a result of disease or decay rather than the cause persisted until the late 1800s. Anton de Bary's careful studies of the life cycle of plant pathogenic fungi during the 1850 s and 1860 s convinced most of his contemporaries that fungi were the cause and not just the result of many plant diseases (Large 1962). During the same period, Pasteur demonstrated that fermentation and microbial growth originate from contamination with microbial cells, setting the stage for further proof that many diseases are caused by microorganisms (Lechevalier and Solotorovsky 1965). In 1876, Robert Koch published his proof that the anthrax disease of sheep was caused by a bacterium. The germ theory of disease now became popular, resulting in a rash of publications reporting many diseases as being caused by microorganisms, sometimes solely because a microorganism had been found in the diseased organism.

Koch, Pasteur and Brefeld realized the importance of methods to obtain pure cultures of microorganisms outside the plant or animal body. Use of these techniques could dispel the uncertainty associated with the use of inoculum directly from the diseased organism, namely that any microorganism in the inoculum might be contaminated with others or with toxic substances that could be the real cause of the disease. In 1882, Robert Koch formulated the now generally accepted rules for proof of pathogenicity that have become known as Koch's Postulates. These are:

1. The suspected pathogen must always be found to be associated with the disease (complex of symptoms) in question. When the disease is present, the pathogen must be found in the plant or animal body. Conversely, when the pathogen is present in characteristic locations and numbers, symptoms of the disease must develop.

2. The suspected pathogen must be isolated, grown in pure culture to free it from any contaminants from the diseased organism, and be studied and described exhaustively.

3. The organism from the pure culture must be inoculated into a healthy host of the same species and variety as the original host; the resulting symptoms must be compared with those of the original specimen and found to be exactly the same.

In 1901, the American plant pathologist Erwin F. Smith, in a

Anton B.A.M. Baudoin is an assistant professor, Department of Plant Pathology, Physiology and Weed Science, Virginia Polytechnic Institute and State University, Blacksburg, VA 24061. He obtained his M.S. in plant protection at the State Agricultural Univ. at Wageningen, the Netherlands (1975), and his Ph.D. in plant pathology at the University of California at Riverside in 1980 . He has been at VPI\&SU since 1981, teaching courses in plant pathology, epidemiology of plant diseases, principles of plant disease control, and integrated pest management. Baudoin's research interests include weed pathogens that might be developed as biological control agents, and effects of plant tissue water status on soft rot diseases. He is a member of the American Phytopathological Society (currently chairs the teaching committee), Virginia Academy of Science, Sigma Xi, National Association of Colleges and Teachers of Agriculture and the Weed Science Society of America. 
dispute with the German botanist Alfred Fischer who questioned that bacteria could cause plant diseases, added a fourth requirement:

4. The microorganism must be reisolated from the inoculated host, compared with the first isolate, and found to be the same, in order to prove that it multiplied and spread in the host.

\section{Preparation and Sources of Materials}

The host-parasite systems that I have used successfully to demonstrate Koch's Postulates are listed in Table 1. Additional systems are described in the references. Considerations in the choice include:

1. The pathogen should produce the structures necessary for identification on the host organ or in potato dextrose agar (PDA) culture.

2. Typical symptoms should develop rapidly on susceptible hosts, preferably within a week.

3. Some fungi such as Rhizopus and Penicillium produce large numbers of air borne spores, which easily contaminate the cultures of other students in the room. These pathogens are best avoided, unless a laminar-flow hood is available in which students can transfer their cultures.

The number of different diseases available is not important, as long as not too many students receive the same disease. One pathogen can be presented on different hosts, such as Penicillium digitatum on lemon, orange and grapefruit. Ten different pathogens with a number of hosts may be enough for a 30-student class. Decaying fruits and vegetables can be obtained directly from supermarkets and given to the students. However, to ensure variety, I find it more convenient to maintain a collection of cultures for inoculation. A culture collection can be built up over the years from specimens collected from grocery stores, gardens, plant disease clinics and cultures obtained from colleagues or from the American Type Culture Collection (12301 Parklawn Drive, Rockville, MD 20852-1776). For interstate shipment of plant pathogens, you must obtain a permit from the U.S. Department of Agriculture, Plant Quarantine Division, ARS, Federal Center Building, Hyattsville, MD 20782.
The exercise takes 4-5 weeks to complete and is best conducted after students have learned something about fungi and bacteria. If started earlier, the students will have to carry out their initial disease description with little background to aid in their interpretations. Actually, some instructors may prefer this, since it will force the students to describe and sketch what they actually see, rather than what they think they should see. At the end of the project, there will be a second opportunity to describe the disease on the inoculated host.

Pathogen cultures on PDA plates should be started about three weeks before the date needed. This requires 10 minutes if plates have been prepared previously.

Host fruits and vegetables may be obtained from a grocery store and inoculated about one week before the date needed. Some pathogens, such as Pythium sp. and Erwinia carotovora, progress more rapidly and should be inoculated 3-4 days before the date needed. Inoculation requires about two hours for $60-70$ specimens. I use a small cork borer to remove a plug from the host tissue, and I leave this plug in the cork borer while I use the latter to cut a plug from the culture plate. Then I insert the culture plug with the host tissue plug on top of it in the hole in the host, using a rod to push the plugs out of the cork borer. I cover the wound with a piece of tape or a little petroleum jelly, and store the specimens in small plastic bags.

The following equipment should be available for all steps of this exercise:

One per 2-4 students: compound microscope dissecting microscope

box of microscope slides

box of cover slips

bottle of immersion oil and lens paper

dropper bottles with distilled water, Gram staining solutions, phenol, $4 \% \mathrm{KOH}$, or $1 \%$ cotton blue, aniline blue, or basic fuchsin in lactophenol or water (Dhingra and Sinclair 1985).

double-stick scotch tape

bottle of disinfectant (Roccal or $10 \%$ bleach (Clorox or equivalent))

beaker or jar with $95 \%$ alcohol (for flaming needles, etc.)

paper towels-as needed

bunsen burner

book of matches or striker

Kimwipes, Kleenex or similar absorbent paper

marking pen (for petri dishes, slant cultures, etc.)
One per student:

transfer loop

transfer needle

scalpel

razor blade (single-edged)

forceps

dissecting needle

\section{Procedures}

First period: steps 1 and 2, Disease Observation and Pathogen Isolation (requires 60-90 minutes).

Required: diseased fruits and vegetables

PDA plates -2 or 3 per student

sterile water in small tubes (one per student; not all will need it)

sterile paper towels

Since the students will have only one or a few specimens to study, this will limit their ability to confirm "constant association." From the specimen(s) available, they should examine, draw and describe symptoms and pathogen structures: (1) macroscopically; (2) under low magnification looking for fungal fruiting structures and the like; and (3) microscopically by preparing scrape or squash mounts or thin sections, and staining them (Schaad 1980; Dhingra \& Sinclair 1985).

This phase of the investigation may give the students some clues regarding the best way to attempt isolation of the pathogen. The two most practical methods are:

1. Tissue plating, especially if observation shows mainly fungal mycelium and few spores or bacterial cells in or on the plant tissue. Small pieces of diseased tissue may be cut from the edge of the lesion, surface disinfected by dipping in bleach (10 or $20 \%$ Clorox or equivalent), blotted on sterile paper towel, and placed on PDA in a petri dish.

2. Dilution or streaking, especially useful if numerous fungal spores or bacterial cells are observed in or on the plant tissue. If spores are present on the tissue surface, students should try to pick some off with a needle (under a dissecting microscope if desired) and streak them on an agar plate. If spores or bacterial cells are found inside the tissue, a small piece of diseased tissue should be cut up in a drop of sterile water on a sterile surface (for instance, in a petri dish) and some of the resulting suspension streaked on PDA. 
Second period: step 2, Transfer to Pure Culture (requires 10 minutes).

Required: PDA slants (2-4 per student)

additional PDA plates (for second isolation attempt, if needed)

Students should check their isolation plates 2-4 days later and transfer any organisms that have grown to slants. If the next scheduled lab is a week later, students might do this outside class hours, or you may store plates that show rapid growth in the refrigerator for a few days.

The question "How can you be sure that you have a pure culture?" should be discussed. Visual inspection, even through a microscope, is not conclusive since one organism may produce different types of spores and mycelium, and because different bacterial cells or fungal hyphae or spores may look very similar. This was a real problem in the days before Koch and Pasteur, because it was often thought that disease might be caused by a poison present in the inoculum, together with the bacterial or fungal cells. Pasteur addressed the problem by repeated subculturing of broth cultures which were each inoculated with a minute amount of inoculum, until one had to assume that any poison would have been so diluted as to be no longer present. However, this technique does not guarantee pure cultures. Koch, working with bacteria, developed the use of solid media on which one could streak out the material with the microorganisms and subculture from a single developing colony, which presumably originated from a single cell. This technique works with fungal spores as well and has the advantage that one can see how many different organisms were present in the material that was streaked out. Brefeld, working with relatively large-spored fungi, was able to pick out individual spores and start his cultures with those. In advanced courses or as an option for interested students, several of these techniques could be attempted with sporulating fungi and bacteria.

Third period: step 3, Inoculation of a Host (requires 15-20 minutes).

Required: healthy hosts.

Students may be asked to procure their own fruit or vegetable from a grocery store. I also ask students to bring an empty peanut butter jar or equivalent container to incubate their specimen. For students who forget to bring one, I have spare jars or plastic bags. Jars are better than plastic bags, since fruiting structures on the host surface will not be crushed, and be- cause the mess is better contained if students keep their rotting specimen too long.

Many of the postharvest diseases listed in Table 1 require a wound for infection, and wound-inoculation works with all of them. Students may be encouraged to experiment with inoculation methods. The amount of inoculum required to achieve infection can also be studied. Some students turn this step into a little research project.

Suggested inoculation methods:

1. Rub the host surface with $95 \%$ ethanol and let dry. Make a cut in the host tissue with a scalpel and insert a piece of agar culture.

2. Tape a piece of agar with the mi- croorganism to the intact host surface, and place a drop of water at the edge of the agar to provide sufficient moisture.

3. Place drops of spore or cell suspension on the host surface (within a ring of petroleum jelly if needed). Prick with a needle into the host tissue through some of the drops, while leaving intact the tissue under other drops.

The instructor should discuss possible sources of error and stress the need for control inoculations (inoculations with distilled water or a sterile piece of agar) to check for contamination or quiescent infections that may already be present in the host. Stu-

Table 1. Selected diseases of fruits and vegetables suitable as "unknowns" for an exercise in disease diagnosis following Koch's Postulates

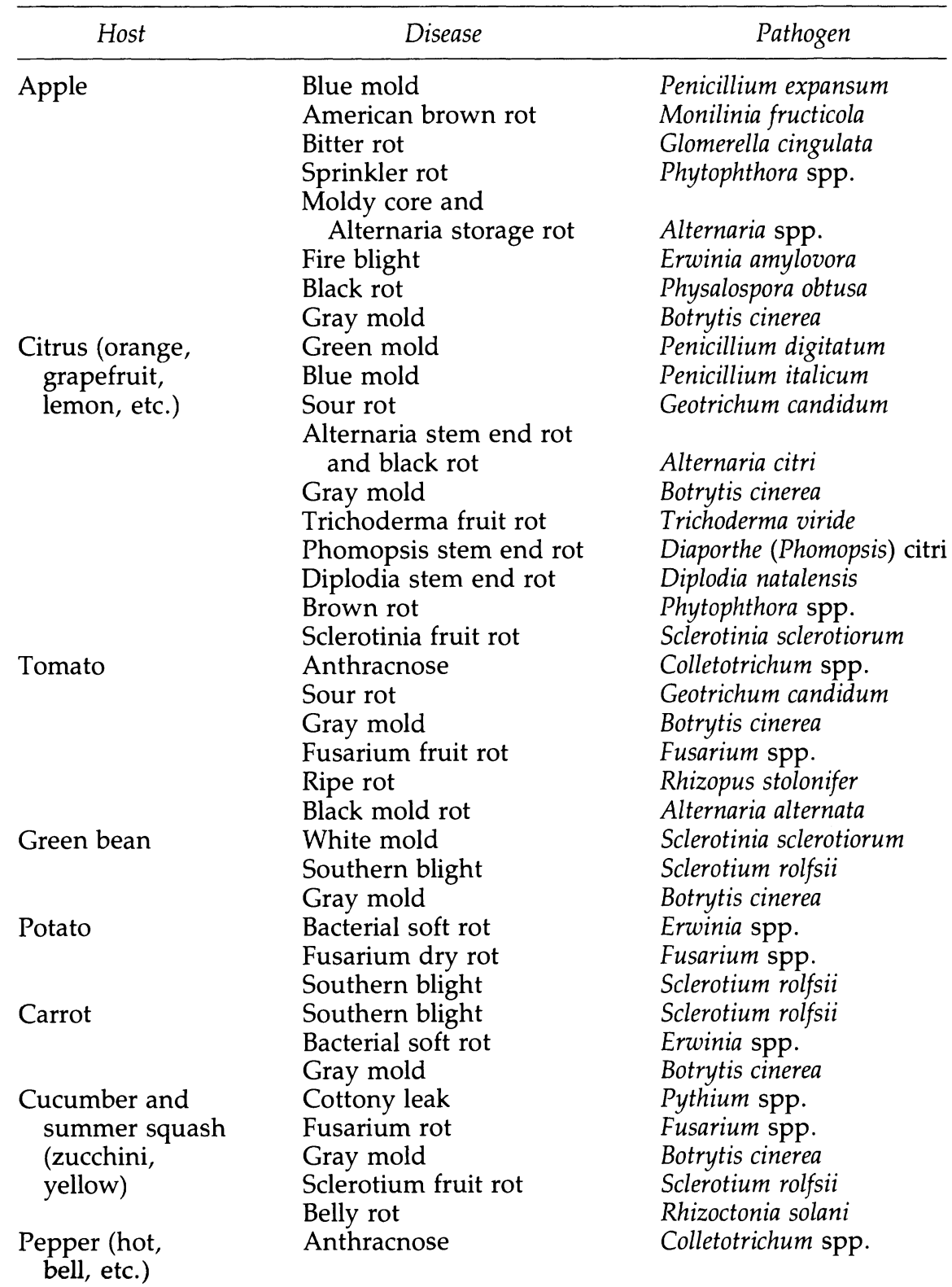


dents should include such controls. Also, the need for replication in reallife experiments should be mentioned. In some cases, the inoculation will not result in disease.

Possible explanations include:

1. The organism isolated was not the pathogen that caused the original disease.

2. The host may not have been susceptible. One may have used a cultivar resistant to the disease (although this is not likely with most of the host-parasite systems suggested), or the host may have been at a less susceptible stage. Fully mature fruits and vegetables are much more susceptible to many storage diseases than immature hosts.

3. The inoculum may have been insufficient in quantity. Although one fungal spore or bacterial cell in principle can cause infection the likelihood may be very low. Concentrated inoculum may be necessary to ensure a high probability of infection.

Fourth period: step 4, Reisolation (requires 15-20 minutes).

Required: PDA plates -2 per student

The same techniques used in the original isolation can be used. The original isolate should also be transferred to a fresh slant or plate, to provide cultures of the same age for comparison.

Identification (step 5) may be started at this time, or wait until the next week.

Step 5: Comparison of the Reisolated Organism with the Original Isolate, and Identification of Pathogen.

Required: reference books (see references below)

some bacteriological media (e.g. King's B medium, Schaad 1980)

Gram stain solutions

Beginning students will need a lot of help, if they are to be successful in identifying their unknown, but it does provide a very useful exercise and generates a genuine sense of satisfaction. I generally ask several advanced students to help out with this particular step. Alternatively, if identification of fungi and bacteria is not an important goal of the course, students might just be asked to prepare a detailed description of the pathogen and a list of similarities (and differences, if any) between the first and second isolate.

There are basically two approaches that can be taken to identify an unknown pathogen:
1. Start with references (listed at the end of this article) that describe diseases of specific hosts or groups of hosts, and look for symptom descriptions or pictures that match the disease. Then look up the corresponding pathogens in the references that describe fungi and bacteria.

2. Start with the pathogen isolated and key it out using one of the references cited (e.g. Barnett and Hunter 1972, Schaad 1980, Streets 1972). Then verify the conclusion using books on diseases of the host in question to check whether an organism of that name has been described as causing a disease with the symptoms observed.

Although this exercise can be conducted with all students in a class working with the same disease, I have found it more instructive and challenging if individual students have their own "unknown" disease. This provides several advantages:

1. Giving an unknown presents a problem, which, although solvable, is not guaranteed to end in success. This tends to stimulate student motivation (McKeachie 1965).

2. In this exercise, the students use many techniques that are used in microbiological practice and in diagnosis of fungal and bacterial diseases. If they have to make some decisions themselves, e.g. how to isolate and how to inoculate, they will think about the procedures and develop a better understanding then when everything is prescribed.

3. This exercise demonstrates that similar disease symptoms, such as fruit rot, may be caused by several different pathogens, and that microscopic examination and culturing are often necessary for correct diagnosis.

\section{References}

Barnett, H.L. \& Hunter, B.B. (1972). (3rd ed.). Illustrated genera of imperfect fungi. Minneapolis: Burgess Publishing Co.

Dhingra, O.K. \& Sinclair, J.B. (1985). Basic plant pathology methods. Boca Raton: CRC Press.

$\rightarrow$ Fulton, M.M. (1981). A simple lab exercise demonstrating Koch's postulates. American Biology Teacher, 43, 394.

Large, E.C. (1962). (2nd ed.). The advance of the fungi. New York: Dover Publishing.

Lechevalier, H.A. \& Solotorovsky, M. (1965). Three centuries of microbiology. New York: McGraw-Hill Book Co.

McKeachie, W.J. (1965). Teaching tips, a guidebook for the beginning college teacher. Ann Arbor: George Wahr Publishing Co. Schaad, N.W. (1980). (2nd ed.). Laboratory guide for identification of plant pathogenic bacteria. St. Paul: American Phytopathological Society.

Streets, R.B., Sr. (1972). The diagnosis of plant diseases. Tucson: University of Arizona Press.

Whetzel, H.H. (1918). An outline of the history of phytopathology. Philadelphia: W.B. Saunders Co.

\section{Additional references for use in pathogen identification}

A selection of references useful in diag nosing the postharvest diseases described is given below. In addition, many states have published extension leaflets and bulletins that may be made available to the class.

\section{References on pathogens}

Ainsworth, G.C., Sparrow, F.K. \& Sussman, A.S. (1973). The fungi-an advanced treatise, Vol IVA. A taxonomic review with keys: Ascomycetes and Fungi Imperfecti. New York: Academic Press.

Barnett, H.L. \& Hunter, B.B. (1972). (cited above).

Krieg, N.R. \& Holt, J.G. (Eds.). (1984). Bergey's manual of systematic bacteriology. Vol. 1. Baltimore: Williams \& Wilkins. [Based on Buchanan, R.E. \& Gibbons, N.E. (Eds.). (1974) (8th ed.). Bergey's manual of determinative bacteriology. Baltimore: Williams \& Wilkins].

Streets, R.B., Sr. (1972). (cited above).

Schaad, N.W. (1980). (cited above).

\section{References on diseases of specific crops or groups of crops}

Anderson, H.W. (1956). Diseases of fruit crops. McGraw-Hill, New York.

Anonymous. (1960). Index of plant diseases in the United States. Agricultural Handbook No. 165. Washington DC: Agricultural Research Service, USDA. (currently out of print).

Chupp, C. \& Sherf, A.F. (1960). Vegetable diseases and their control. New York: Ronald Press Co.

Fawcett, H.S. (1936). (2nd ed.). Citrus diseases and their control. New York McGraw-Hill Book Co.

Hooker, W.J. (Ed.) (1981). Compendium of potato diseases. St. Paul: American Phytopathological Society

Jones, A.L. \& Sutton, T.B. (1984). Diseases of tree fruits. East Lansing: Cooperative Extension Service, Michigan State University.

Klotz, L.J. (1961). (3rd ed.). Color handbook of citrus diseases. Berkeley: University of California Press.

Knorr, L.C. (1973). Citrus diseases and disorders. Gainesville: University Presses of Florida.

MacNab, A.A., Sherf, A.F. \& Springer, J.K. (1983). Identifying diseases of vege- 
tables. University Park: Pennsylvania State University.

Vock, N.T. (1978). Handbook of plant diseases in colour. Vol 1. Fruits and vegetables. Brisbane, Australia: Queensland Department of Primary Industries.

Walker, J.C. (1952). Diseases of vegetable crops. New York: McGraw-Hill Book Co.

Wilson, E.E. \& Ogawa, J.M. (1979). Fungal, bacterial, and certain nonparasitic diseases of fruit and nut crops in California. Berkeley: Division of Agricultural Sciences, University of California.

The U.S. Department of Agriculture (Washington DC) has published many booklets on market diseases of various fruits and vegetables which are comprehensive and show color photographs of symptoms. Unfortunately, virtually all of them are out of print, but they may be available in libraries. The following are the most useful:

Anonymous. (1959). Market diseases of beets, chicory, endive, escarole, globe artichokes, lettuce, rhubarb, spinach, and sweet potatoes. Agricultural Handbook No. 155.

Smith, W.L. \& Wilson, J.B. (1978). Market diseases of potatoes. Agricultural Handbook No. 479

Smoot, J.J., Houck, L.G. \& Johnson, H.B. (1971). Market diseases of citrus and other subtropical fruits. Agricultural handbook No. 398.

Barksdale, T.H., Good, J.M. \& Danielson L.L. (1972). Tomato diseases and their control. Agricultural Handbook No. 203.

Harvey, J.M., Smith, W.L., Jr. \& Kaufman, J. (1972). Market diseases of stone fruits: cherries, peaches, nectarines, apricots, and plums. Agricultural Handbook No. 414

McColloch, L.P., Cook, H.T. \& Wright, W.R. (1968). Market diseases of tomatoes, peppers, and eggplants. Agricultural Handbook No. 28.

Pierson, C.F., Ceponis, M.J. \& McColloch L.P. (1971). Market diseases of apples, pears, and quinces. Agricultural Handbook No. 376.

Ramsey, G.B. \& Smith, M.A. (1961). Market diseases of cabbage, cauliflower, turnips, $\mathrm{Cu}$ cumbers, melons, and related crops. Agricultural Handbook No. 184.

Smith, M.A., McColloch, L.P. \& Friedman, B.A. (1966). Market diseases of asparagus, onions, beans, peas, carrots, celery, and related vegetables. Agricultural Handbook No. 303.

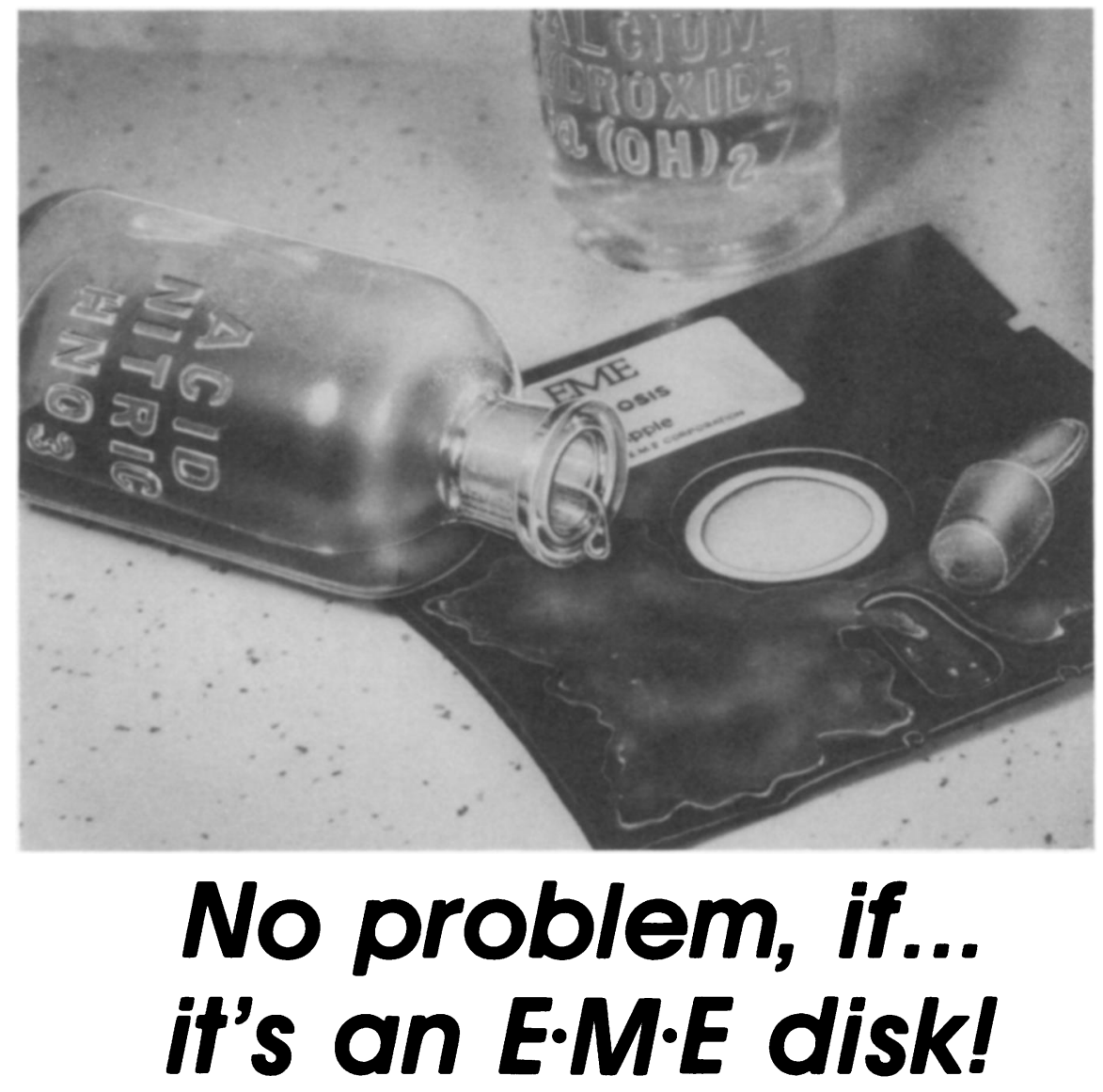

GUARANTEE

If a disk becomes inoperable for any reason, E॰M•E will replace it at no charge.

\section{BIOLOGY • CHEMISTRY • PHYSICS ELEMENTARY SCIENCE}

\author{
For A Free Catalog Call \\ $800345-2050$ \\ Connecticut 203 798-2050
}

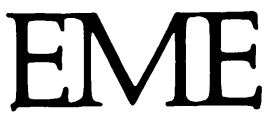

Educational Materials and Equipment Co.

Old Mill Plain Road • Post Office Box 2805

Danbury, Connecticut 06813-2805

Serving Science Education Since 1955 